\title{
The perceived supports for self-care in hemodialysis patients: a qualitative study
}

Nasrin Rezaee

Associate Professor, Community Nursing Research Center, Zahedan University of Medical Sciences, Zahedan, Iran

Maryam Seraji

* Assistant Professor, Health Promotion Research Center, Zahedan University of Medical Sciences, Zahedan, Iran. (Corresponding author):

Email: serajimaryam@gmail.com

Received: 18 October 2019 Accepted: 22 December 2019

Doi: $10.29252 /$ ijhehp.8.2.97

\section{ABSTRACT}

Background and Objective: Following the self-care behaviors is considered as one of the fundamental factors of treatment in hemodialysis patients. Patients' perception of support will control their mental tensions and cause them to follow the self-care behaviors, and then it will promote their general health. The main purpose of the current study was "identification of the perceived supports for self-care in hemodialysis patients".

Materials and Methods: this study was conducted on the base of content analysis conventional. The study participants were 9 patients, 3 families having hemodialysis patients, and 2 nurses working in dialysis section. We made use of purposive sampling and continued gathering the data till we reached data saturation point. Besides, the data gathering procedure was conducted through semi-structured interviews. Finally, the data was analyzed through content analysis.

Results: The present study's findings included a main category of perceived support and three subcategories of constructive support, destructive support, and individual's feeling of the provided support; and all of these conditions indicated nature and dimensions of the role of perceived support in hemodialysis patients' self-care. Conclusion: The findings of this study showed that hemodialysis patients can use the support provided during the illness, including constructive support, destructive support, and one's sense of support to enhance self-care behaviors and improve their quality of life. Therefore, nurses, physicians, and families Hemodialysis patients should pay more attention to patient support.

Keywords: Hemodialysis Patients, Self-care, Perceived support, Qualitative study Paper Type: Research Article.

Citation (Vancouver): Rezaee N, Seraji M. The perceived supports for self-care in hemodialysis patients: a qualitative study. Iran J Health Educ Health Promot. Spring 2020;8(2): 97-106. [Persian]x

Citation (APA): Rezaee N., Seraji M. The perceived supports for self-care in hemodialysis patients: a qualitative study (Summer 2020). Conc... . Iranian Journal of Health Education \& Health Promotion., 8(2), 97-106. [Persian] 
حمايت هاى درك شده خودمراقبتى در بيماران همودياليزى : يك مطالعه كيفى

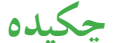

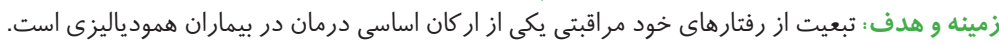

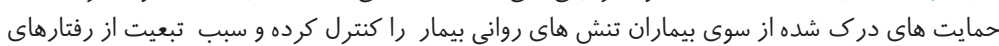

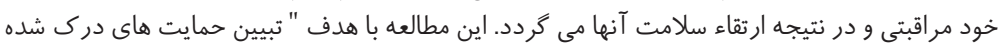

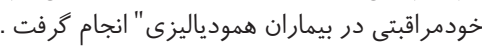

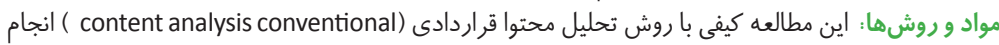

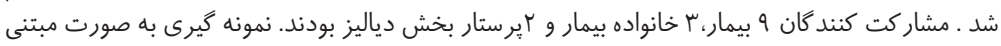

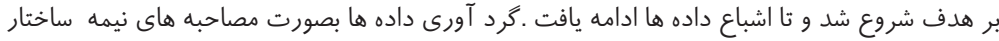

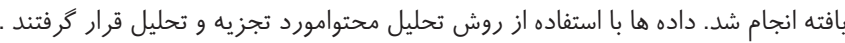

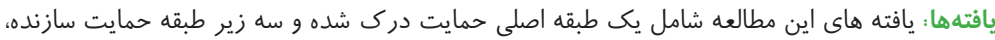

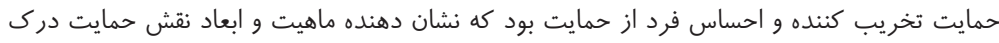

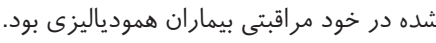

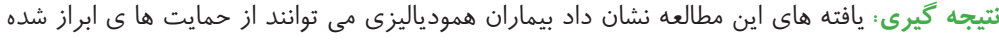

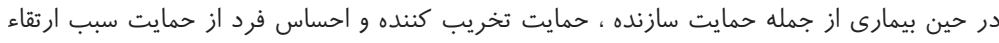

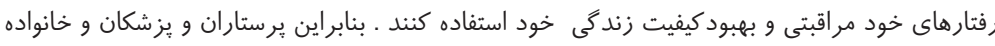

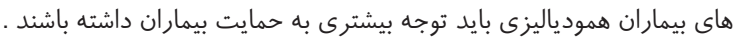

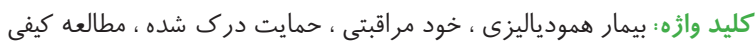
نوع مقاله : مطالعه يزوهشى. بمودئ.

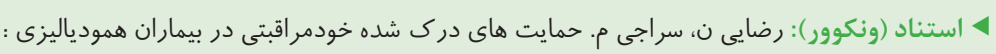

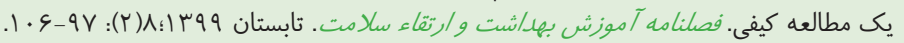

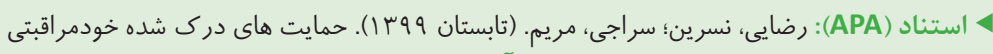

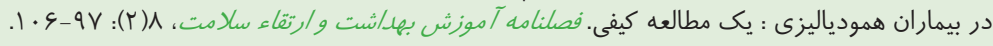

دانشيار، مركز تحقيقات بِر ستارى جامعه ،دانشكاه علوم

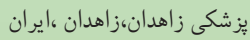

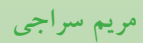
ع * استاديار، مركز تحقيقات ارتقاء سلامت ، دانشكاء

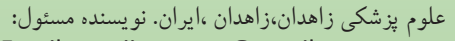
.Email: serajimaryam@gmail.com

تاريخ د ريافت: ت تاريخ

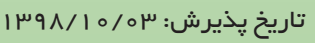


(A-V) (به نظر مى رسد درك و نكرش بيماران نسبت به حمايت

دريافتى ، مهم تر از ميزان حمايت ارائه شده به بيماران مى باشد . . علاوه بر اين رضايت از حمايت اجتماعى درك شده از سوى بيماران با كاهش اضطراب و افسردگى و غلبه بر خود بيمارانكارى همراه بوده و افزايش اعتماد به نفس و گسترش روابط اجتماءى وارتقاء كيفيت زندگى را به دنبال دارد(9). مطالعه Brune نشان دادكه حمايت خانواده بيشترين تاثير را در جنبه هاى مختلف زندگى

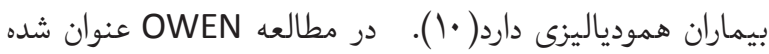
است كه بيماران با حمايت اجتماعى درك شده بر توانييى خود جهت انجام رفتارهاى خودمراقبتى اطمينان بالاترى دارند( (I)). در مطالعه Boosman هايى كه به واسطه عوارض بيمارى در آنها ايجاد شده است شكايت داشتند و اين را يك محدوديت براى خود مى دانستند( آI). نتايج وايج مطالعه كيفى نشان داد برخوردارى از حمايت در رفتارهاى ييشگيرانه سلامت موثر بوده است بنابراين در افراد بيمار كه به حمايت بيشترى

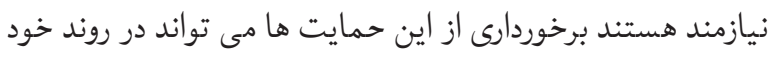

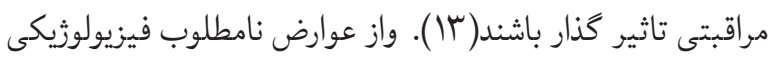
بيمارى جلوكيرى نموده و تاثير مثبتى بر وضعيت جسمى، روانى و اجتماعى فرد بر جاى كذارد و در نهايت به افزايش عملكرد و

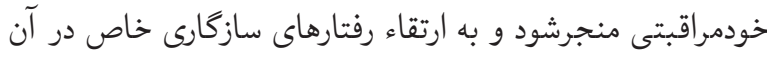
ها كمك كرده و حمايت هاى محيطى مناسبى را براى آنان فراهم

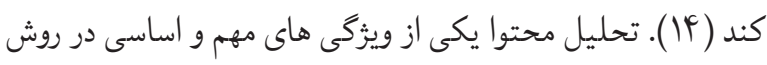

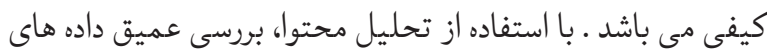

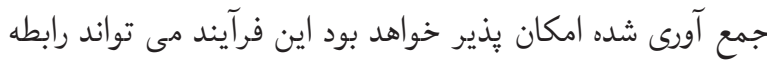
متغيرها و شبكه هاى ارتباطات را نه در سطح و بلكه در عمق مشاهده و بررسى نمايد. در واقع هدف تحليل محتوا، استنباط، استنتاج و شناخت نسبى شرايط توليد موضوع به كمك شاخص ها مى باشد، هردئ شاخص هايى كه غالبا هنهان هستند و باتوجهبهاينكه در مطالعات كيفى ارتباط نزديكى با مشاركت كننده وجود دارد لذا مفهوم حمايت و درك از حمايت از سوى بيماران با شفافيت بهترى مى تواند مورد
سازمان بهداشت جهانى بيماريهاى مزمن را طولانى مدت، ناتوان

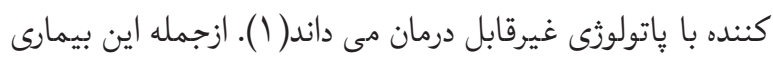

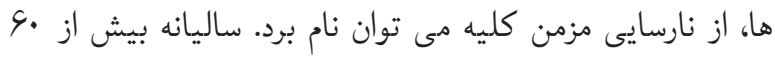

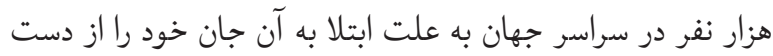
مى دهند. بيمارى و روش درمانى همودياليز شيوه زندگى، وضعيت

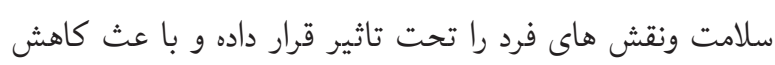
كيفيت زندگى، مشكلات جسمى، مشكلات روانى و محدوديت

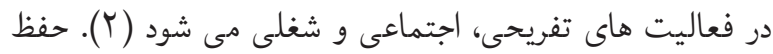
سلامتى بيماران ESRD بستكى به جهارجنبه درمانى دارد كه شامل محدوديت مصرف مايعات، احتياطات رثيمى(كم نمك،كم يتاسيم،كم بهم فسفرو...) ،مصرف داروهاى توصيه شده وشركت منظم درجلسات دياليزمى باشد. مى توان مجموعه اين مواردرارفتارهاى تبعيت ازدرمان دربيماران همودياليزدانست(ץ). روش درمان همودياليز و تبعيت

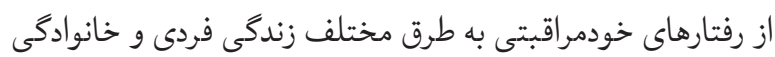
بيماران را تغيير مى دهد و بيماران تحت درمان بايستى هر هفتئه دو تا سه نوبت و در هر نوبت جند ساعت دور از خانه باشد كه اين

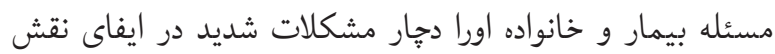

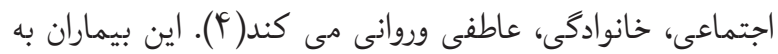

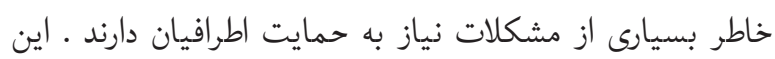

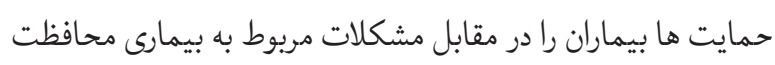

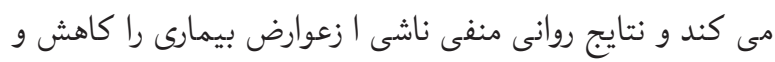
سازگارى وتبعيت از رفتارهاى خودمراقبتى كه يكى از اركان اساسى رسى درمان بيماران همودياليزى است را افزايش مى دهد (ه). در اين

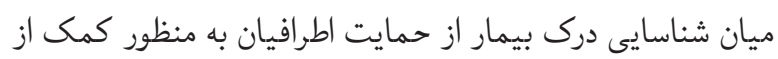

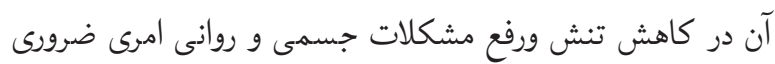
است (9). حمايت هاى درك شده از سوى اطرافيان توسط بيمار به عنوان يكى از مكانيسم هاى مقابله ایى عاطفه نكر، داراى قدرت

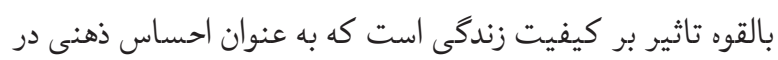

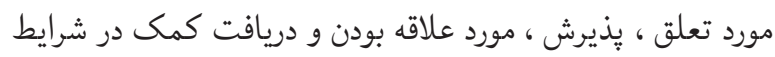

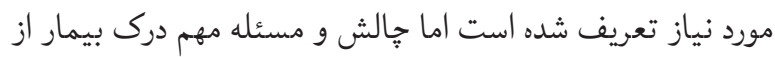


"منظورتان جِيست؟ " برسيده مى شد و براساس پِاسخ ها، سوالات بعدى مطرح مى شد . تمام مصاحبه ها توسط محقق انجام شد. براى ترك تحليل داده ها ابتدا مصاحبه هاى ضبط شده بصورت كلمه به كلمه پياده و تايب شدند. قبل از كد گذارى مصاحبه ها جند نوبت خوانده و كوش داده شد. سيس مصاحبه خط به خط براى شناسايى واحد هاى تهاى

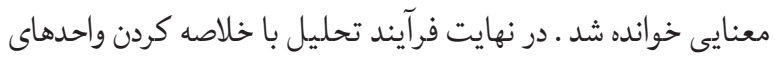
معنايى به كدها، زير طبقات و طبقات اصلى خاتمه يافت . طول مدت

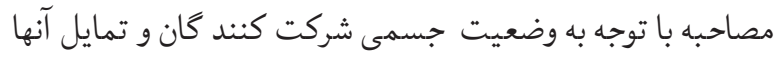

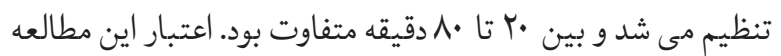

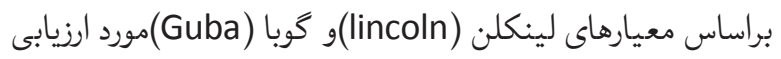
قرار گرفت و از f معيار اعتبار، تاييديذيرى، قابليت اعتماد و انتقال يذيرى استفاده گرديد(10). يكى از بهترين روش ها براى ايجاد اعتبار

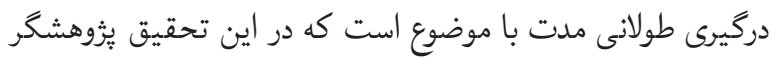
به مدت باماه با موضوع تحقيق و بيماران همودياليزى درگير بود.

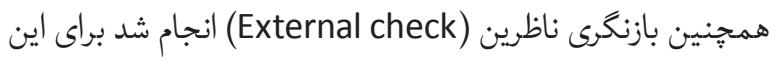

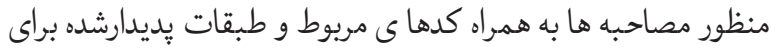
جند نفر از اعضاء هيئت علمى( F نفو) كه در كار مطالعه كيفى خبره

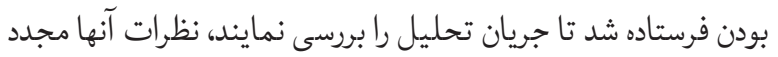

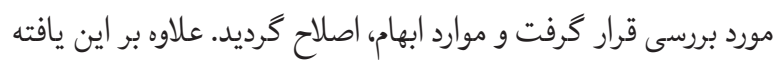

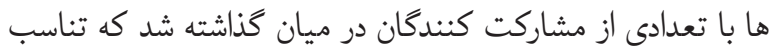

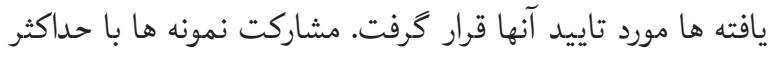
تنوع به تناسب يا انتقال يذيرى يافته ها كمك نمود در اين مطالعه

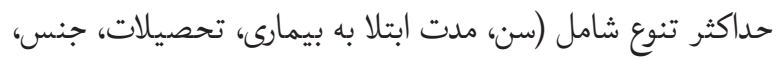

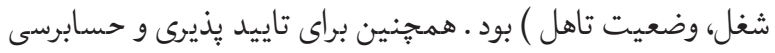

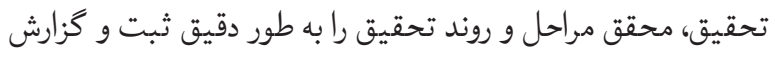
نمود تا امكان بيخيرى تحقيق براى ديكران فراهم شود.

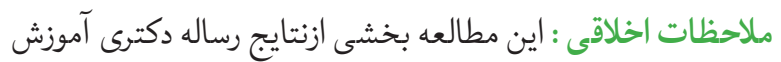

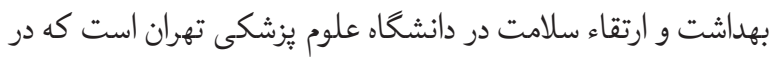
كميته اخلاق دانشعاه ( IR.DTUMS.REC.1394.1665) بررسى لئى و تاييد كرديد .به مشاركت كنندگان در مورد محرمانه بودن مطالب دمالب

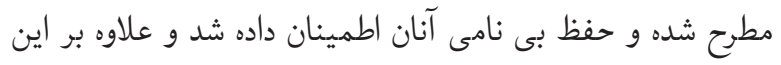

شناسايى قرار گيرد از طرفى نتايج مرور متون در كشور ايران نشان مى دهد بيشتر در خصوص بيماران دياليزى به مسائل مراقبتى و درمانى يرداخته شده است لــذا مطالعه حاضريا هدف تبيين حمايت هاى درك شده خودمراقبتى در بيماران همودياليزى انجامخرفت.

$$
\text { روش كار }
$$

مطالعه حاضريك مطالعه كيفى است كه به روش تحليل محتوا قراردادى انجام شد. عرصه يُوهش بخش هاى همودياليز بيمارستانهاى على

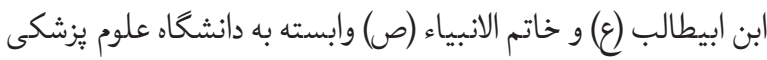

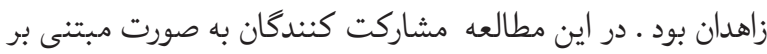
هدف در مطالعه شركت كردند همجِنين كسانى وارد يُزوهش شدندكه تجربه كافى در مورد موضوع مورد مطالعه داشتند، مشاركت كننده اول

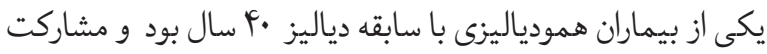

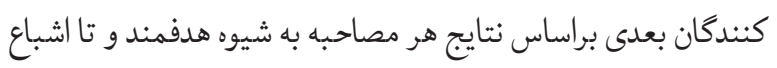
داده ها ادامه يافت. معيارهاى انتخاب مشاركت كنندكان شامل، بيمار با سابقه 9 ماه همودياليز، داشتن هوشيارى و توانايى گفتكو، عدم

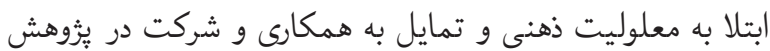

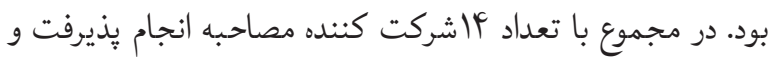

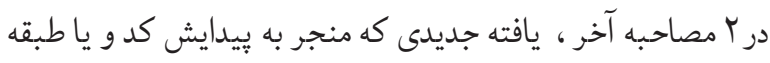
جديدى شود به دست نيامد و اين امر نشان دهنده اشباع داده ها بود . روش گرد آورى داده ها در اين مطالعه مصاحبه هاى نيمه ساختار يافته بود و ياسخ افراد روند مصاحبه هاى بعدى را هدايت مى كرد. مصاحبه

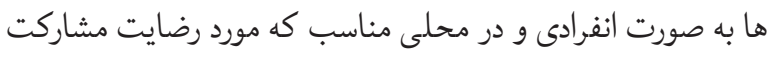
كنندكان بود و در آنجا احساس راحتى مى كر كردند انجام كرفت ـ ـابتدا

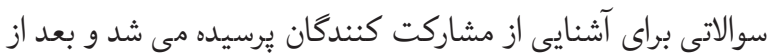
آن سوالات اختصاصى تر مرتبط با هدف يثوهش مطرح مى گرديد

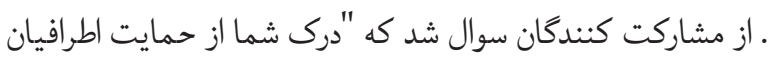
جيست؟ "جه رفتارها و كمك هايى در مدتى كه دياليز مى شويد روى شما تاثيرگذار بوده است؟ همجنين از آنها خواسته شد جزئيات احساسات و حوادث را براى محقق بيان نمايند گاهى اوقات سوالات اكتشافى همحِون "مى توانيد در اين مورد بيشتر توضيح دهيد؟ براي 
هدف استفاده از ضبط صوت به مشاركت كنندگان توضيح داده يافتهها

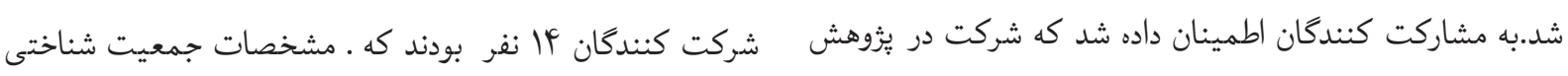

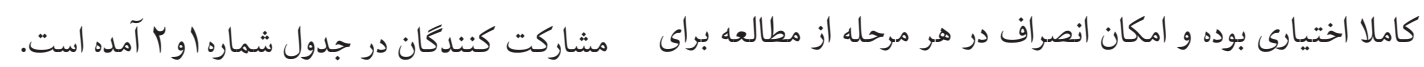
آنان وجود دارد .

جدول ا : مشخصات بيماران همودياليز شركت كننده در مطالعه

تعداد جلسات دياليز

(در هفته) (دمات دالي)

\begin{tabular}{|c|c|c|c|c|c|c|c|c|}
\hline r & فشار خون & r r سال & خانه دار & بى سواد & مجرد & r & زن & 1 \\
\hline r & فشار خون & س سال & خانه دار & ليسانس & متاهل & rV & زن & r \\
\hline r & ديابت & ع سال & بيكار & بى سواد & متاهل & $\Delta r$ & مرد & r \\
\hline r & كلومرونفريت & r F & آز آزاد & دييلم & متاهل & st & مرد & r \\
\hline r & ديابت & ك Sاه & كارمند بانك & ليسانس & متاهل & $i \wedge$ & مرد & $\Delta$ \\
\hline r & عفونت كليه & צr سال & بيكار & ينجم دبستان & مجرد & pr & مرد & 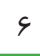 \\
\hline r & مادرزادى & أسال & خانه دار & دييلم & مطلقه & rᄉ & زن & V \\
\hline r & فشارخون & ه سال & خانه دار & بيسواد & بيوه & $\Delta r$ & زن & $\wedge$ \\
\hline r & ديابت & T fr سال & بيكار & سوم راهنمايى & متاهل & pq & مرد & 9 \\
\hline
\end{tabular}

جدول ؟: مشخصات ساير افراد شركت كننده در مطالعه بهائ.

\begin{tabular}{|c|c|c|c|}
\hline سابقه كار(سال ) & مدرى تحصيلى & ارتباط با بيمار & كد \\
\hline - & - & مادر بيمار & 1 \\
\hline - & بى سواد & همسر بيمار & 11 \\
\hline - & سوم راهنمايى & خواهر بيمار & ir \\
\hline$r \mu$ & ليسانس & يرستار & 11 \\
\hline$\wedge$ & ليسانس & يرستار & 14 \\
\hline
\end{tabular}

نتايج حاصل ازتحليل داده هاى حاصل از مصاحبه ها وكدهاى خانواده اينكونه بود: "در ه د درصد موارد خانواده ام به من روحيه اوليه دربر گيرنده يك طبقه اصلى و سه زير طبقه بوداين طبقات و اميد داده اند، هميشه كنارم هستند مثلا الان خانمم با اينكه بايد

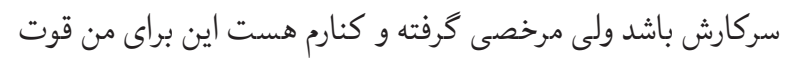

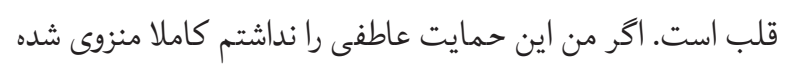

$$
\text { بودم. "(شركت كننده Q) }
$$

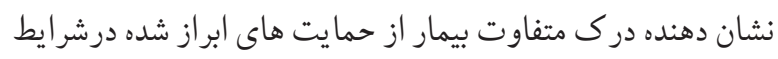
موجودبودند. ماحصل هر يك از طبقات وزير طبقات مربوط به آن در همين راستا نقل قولى از يكى از برستاران ارائه مى كردد: الف:حمايت سازنده نشان دهنده راهبرد حمايتى درخودمراقبتى

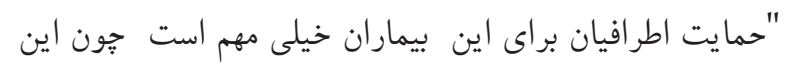

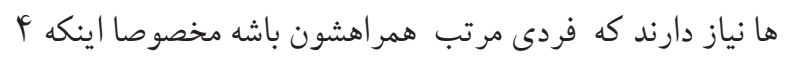

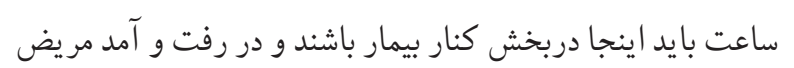

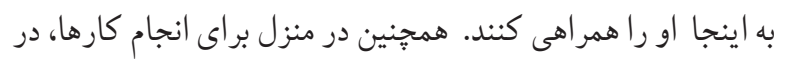
بيماران تحت همودياليز است. زير طبقات اين طبقه شامل "حمايت

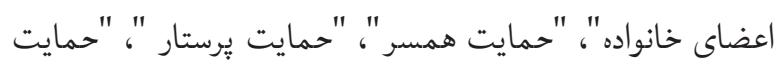

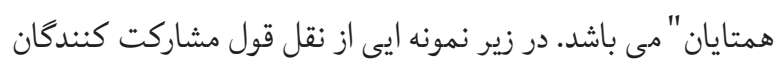
ارائه مى گردد. نقل قول يكى از بيماران در خصوص حمايت اعضاء 
جدول سّ: طبقات و زير طبقات مربوط به حمايت درك شده در خودمر اقبتى بيماران همودياليز

\begin{tabular}{|c|c|c|}
\hline طبقات اوليه & زير طبقات & طبقات اصلى \\
\hline حمايت اعضاى خانواده حمايت همسر & حمايت سازنده & \\
\hline حمايت نادرست اطرافيان & حمايت تخريب كننده & حمايت درك شده \\
\hline 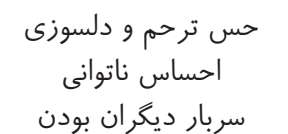 & احساس فرد از حمايت & \\
\hline
\end{tabular}

" تو بخش وقتى با بقيه مريضها ارتباط برقرار مى كنى و مى بينى

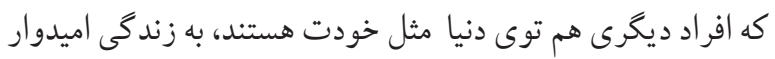

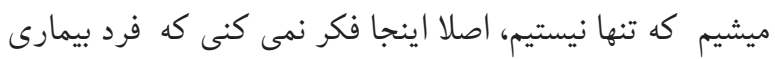

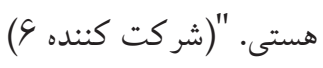
ب- حمايت نادرست اطرافيان: نتايج حاصل از اين مطالعه نشان داد حمايت نادرست خانواده در بيشتر موارد سبب كاهش انكيزه

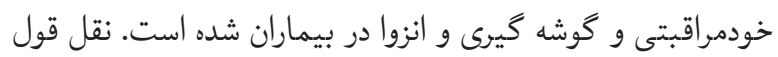
هايى در خصوص حمايت تخريب كننده ذكر مى گردد: " از ديدن

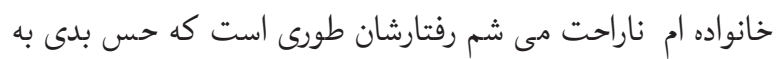
من دست مى دهد. وقتى خانه مادرم مى رم، به محض اينكه وارد

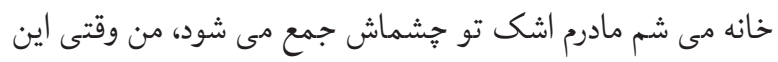

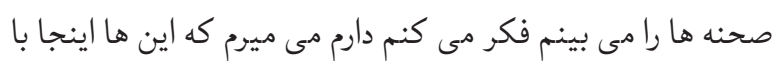

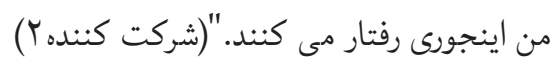

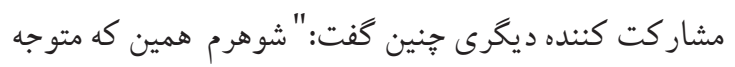

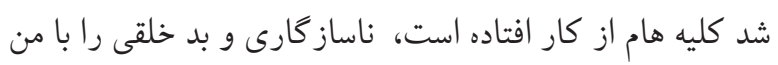

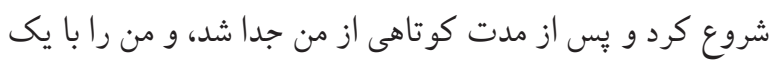

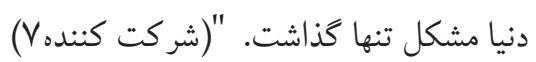

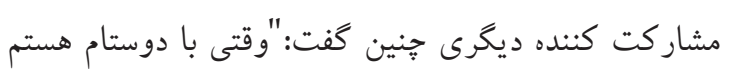

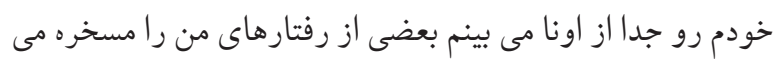

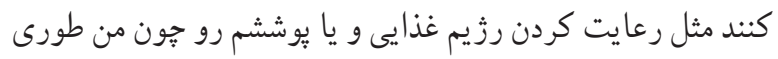

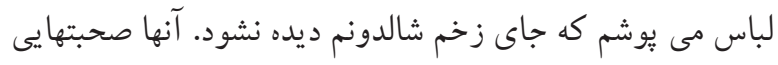
مى كنند كه منو آزار مى دهد اين باعث ميشه كه خيلى سريع از
تهيه دارو بايد به بيمار كمك كنند. مشكلاتى كه در اثر دياليز ايجاد

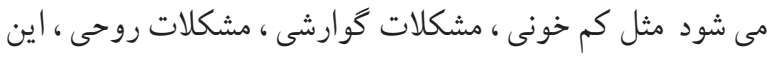

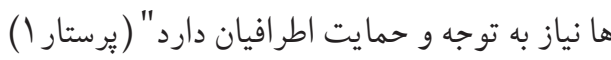
نقل قول يكى از بيماران در خصوص حمايت همسرش اينخونه

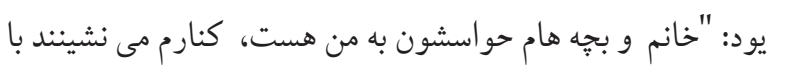
من صحبت مى كنند، اين رفتارشون سبب ميشه من بيشتر از خودم

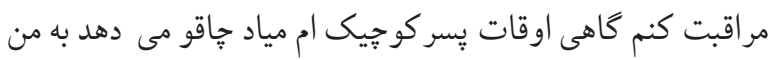

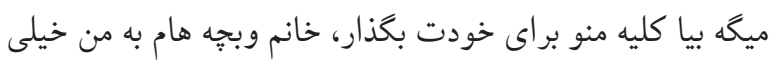

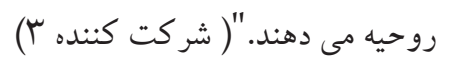
نقل قولى در خصوص حمايت يُرستاران بخش ارائه مى گردد:

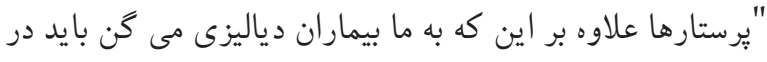

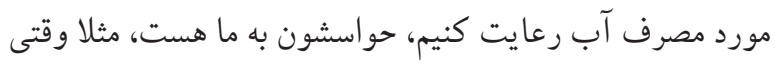

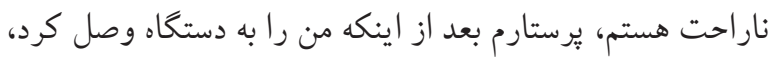
كنارم مى نشيند و با من صحبت مى كند، اينجورى، آخر دياليز

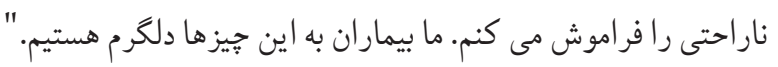

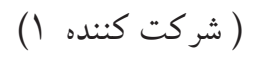

نقل قول ديكرى در خصوص حمايت شدن از سوى ساير بيماران

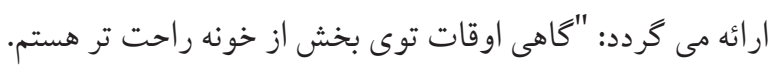

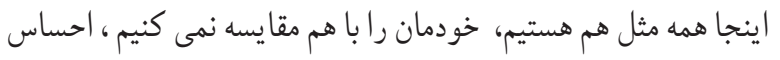

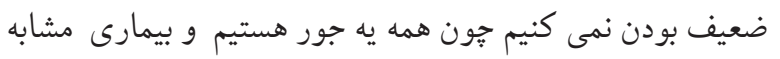

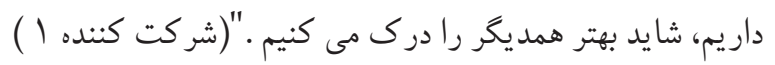
بيمار ديخرى در خصوص حمايت از سوى بيماران جنين گفت 
بحث و نتيجه كيرى اين مطالعه به شناسايى حمايت هاى درك شده در خودمراقبتى

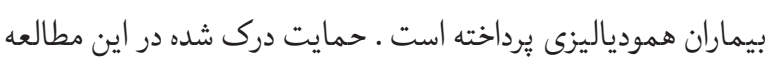

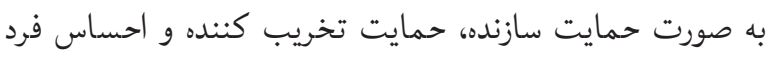

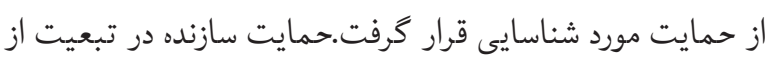

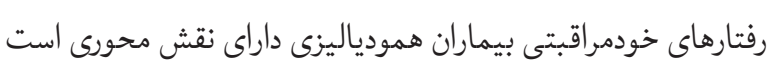

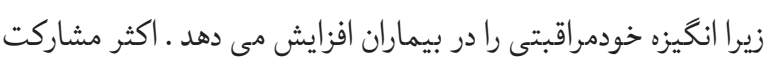
كنندگان بيان مى كردند كه حمايت اعضاء خانواده مثل ( بدر، مادر، خواهر، برادر ) با توجه به شرايط بيمارى برايشان بسيارمهم است دردئ و حمايت و همراهى كردن آنان در رفت و آمد جهت انجام دياليز

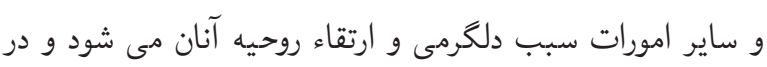

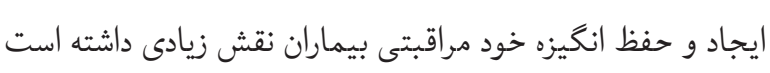

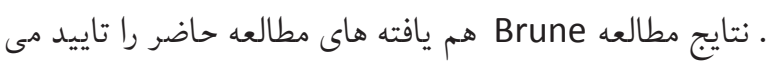
كند كه حمايت هاى خانواده موثرترين نوع حمايت براى بي مايماران همودياليزى در جنبه هاى مختلف مى باشد( •إ). نتايج مطالعه Polaschek

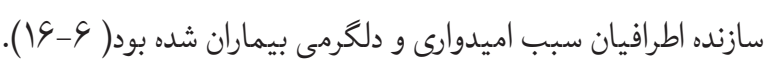
تجارب شركت كنندكان در مطالعه حاضر نشان داد برخوردار بودن از حمايت همسر در ايجاد و حفظ انكيزه خود مراقبتى و شادابى بيماران نقش مهمى دارد وحمايت همسر بيشترين تاثير را بر روحيه بيمار و

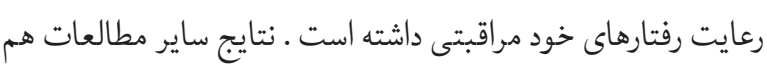
نشان مى دهد كه بيماران همودياليزى متاهل به خاطر برخوردارى از

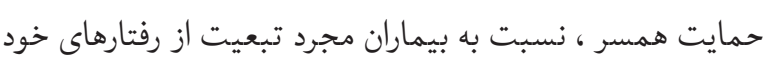

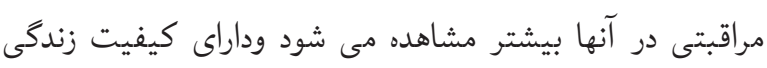

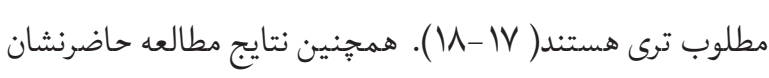
داد نظارت و همدلى برستار بخش در كنار حمايت اعضاء خانواده

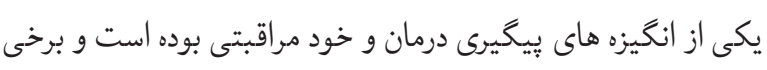

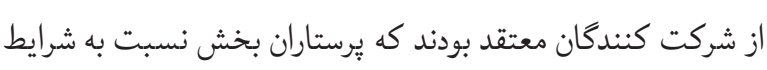

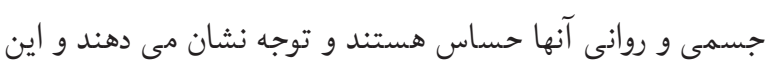

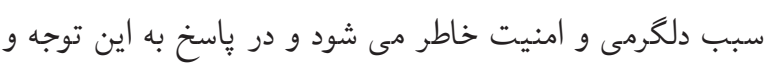

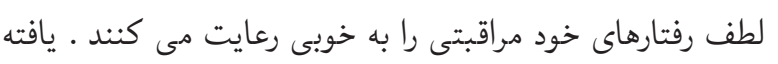

بودن با آنها خسته بشم و دلم مى خواد زودتر به خانه بركردم."

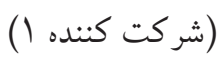
ج- احساس فرد از حمايت : اكثر مشاركت كنندكان اين مطالعه درباره حمايت هاى ابراز شده اطرافيان و احساسى كه از اين حمايت

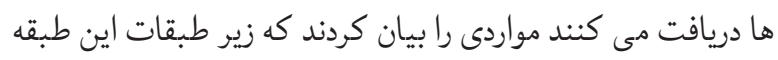

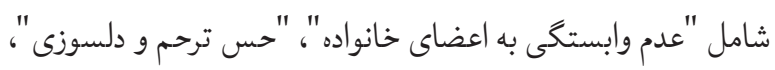
"احساس ناتوانى"، "سربار ديكران بودن" بوده است.

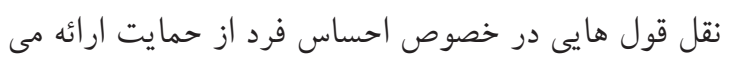

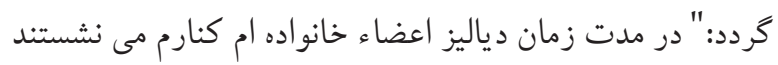

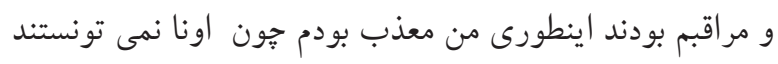
به كارهاشون برسند. احساس عذاب وجدان داشتم كه من آنها را

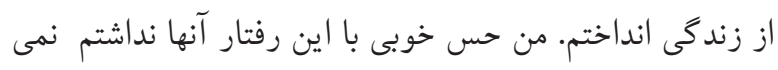

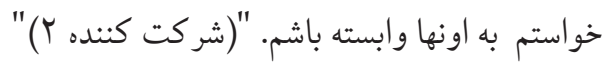
مشاركت كننده ديكرى در خصوص احساس خود جنين كفت:"...

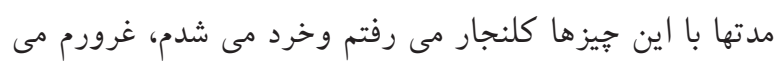

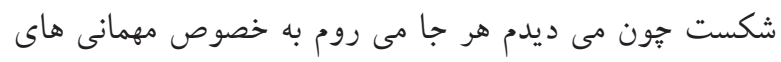

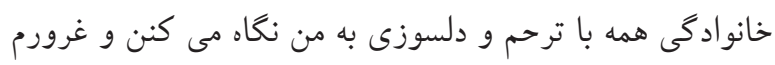

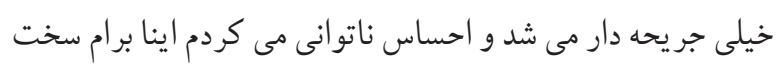

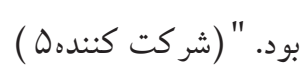
مشار كت كننده ديخرى در خصوص احساس همكارانش نسبت به خود جنين كفت:" در محل كارم، گاهى اوقات كارى كه وظيفه

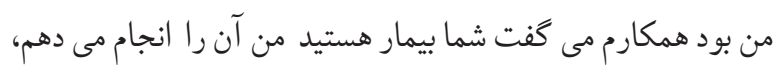

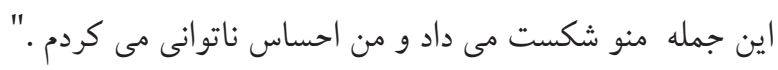

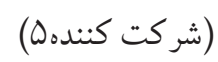
مشار كت كننده ديكرى جنين گفت:"... احساس مى كنم سربار خانو اده هستم همين كه يك روز در ميان من رو واسه جلسات دياليزم

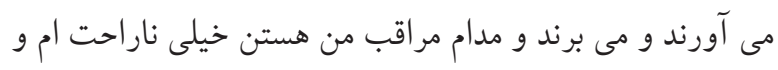

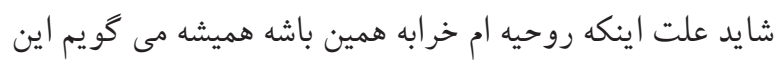

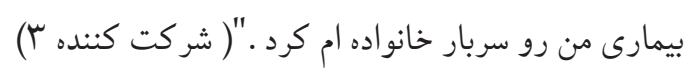


كنندكان بدترين شكل حمايت همسر را جدايى از همسر و طلاق عنوان كردند . يافته هاى مطالعات ديخران در تاييد مطالعه حاضر نشان داد كه جگگنه در هنكام ييشرفت بيمارى ترس از خاتمه رابطه زناشويى وطلاق سبب بروز افسردگى و عدم اعتماد به نفس ترس ترس

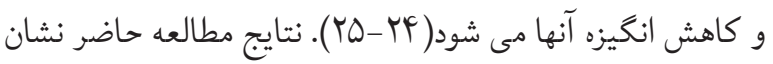

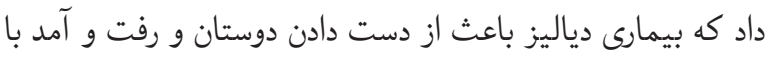
فاميل شده است ـ اين يافته ميتواند بيشتر مورد توجه قرار گيرد زيرا اين گونه رفتارها و عدم توجهات از طرف دوستان و اطرافيان

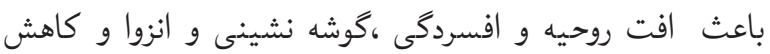
كيفيت زندگى در فرد بيمار شود ـ در ساير مطالعات انجام شده

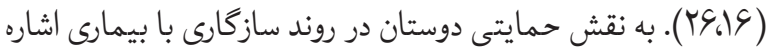
شده است كه با مطالعه ما مغايرت داشت ـ اكثر مشاركت كنندگان

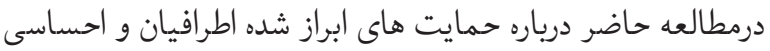
كه از اين حمايت ها دريافت مى كنند را بيان كردند، اينكه بيماران حمايت اطرافيان را جگونه درك كنند بسيار مهم است نتايج مطالعه حاضرنشان داد كه حمايت بيش از اندازه اطرافيان سبب مى شد كه آنها حس خوبى نداشته باشند و نمى خواستند به ديكران وابسته

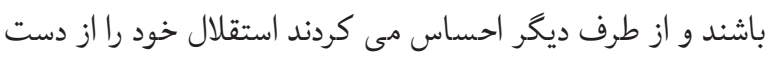
داده اند و تمام اين موارد باعث كاهش انكيزه خود مراقبتى و بيخيرى

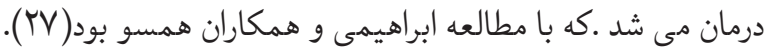
درساير مطالعات نيزبه كاهش وابستكى و استقلال بيمار و فعال شدن مشاركت كنندگان در مراقبت از خود در روند بيمارى تاكيد شده بود و نشان داد كه دركير نمودن بيمار در درمان خود به بيمار

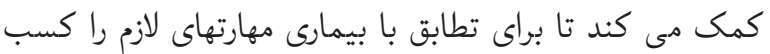

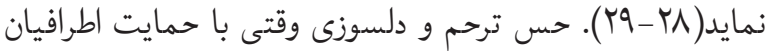

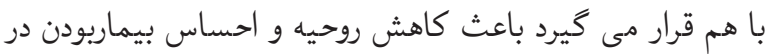

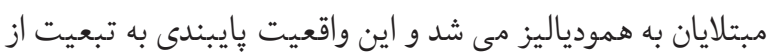
رفتارهاى خود مراقبتى را كاهش مى دهد . ابراز ترحم و دلسوزى از طرف اطرافيان درمطالعه اكثر بيماريهاى مزمن گزارش شده است درد

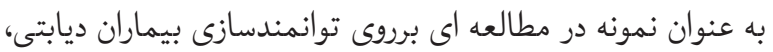

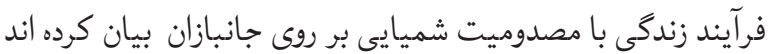

هاى مطالعات ديخر هم بر جايخاه مناسب برستار براى حمايت از

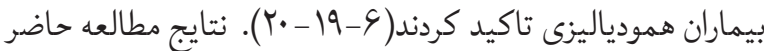
نشان دادكه پيوستن به شبكه حمايتى همتايان و برخوردار شدن از

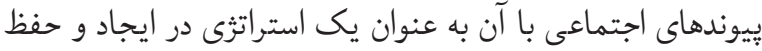

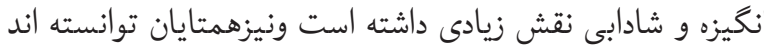
اميد به زندكى و انكيزه خود مراقبتى را در همسانان خود ايجاد كنند · در همين راستا يافته هاى ساير مطالعات نشان داد كه تاثير

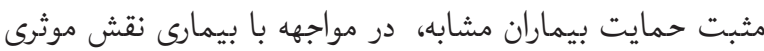

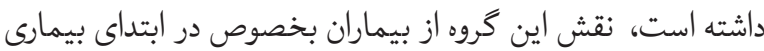

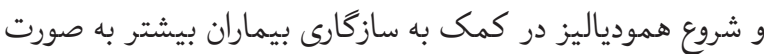
مثبت بوده است (سا). نتايج مطالعه حاضر نشان داد حمايت تخريب كننده اطرافيان در تبعيت از رفتارهاى خودمراقبتى بيماران همودياليزى سبب كاهش انكيزه و افت روحيه و عدم خودمراقبتى مى شود ـ در اكثر موارد وقتى يكى از اعضاء خانواده به بيمارى مبتلا

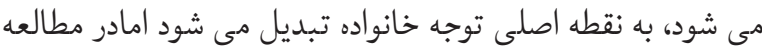
حاضر اين موضوع در مورد بيماران تحت همودياليز به گونه اي ابراز كرديده است كه رفتار اعضاء خانواده حس بد از جمله تنهايى و

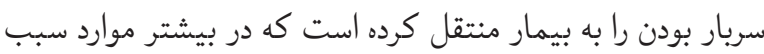

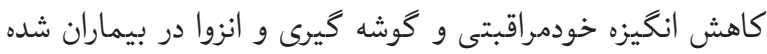
است . نتايج مطالعه حاضر با ساير مطالعات مغايرت دارد كه شايد به دليل مزمن بودن بيمارى همودياليز و عدم شناخت اعضاء خانواده از اين بيمارى سبب درك حمايت معيوب توسط بيمارشده است در حالى كه در ساير مطالعات خانواده مهمترين و اولين منبع حمايتى لمائى است كه از سوى بيمار درك مى شود (·او آY). در ساير مطالعات شركت كنندكان از عدم درك خانواده از موقعيت هايى كه بواسطه عوارض بيمارى در انها ايجاد شده بود شكايت داشتند و اين رايك محدوديت براى خود مى دانستند كه در تضعيف روحيه بيماران

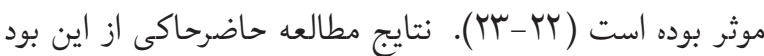
كه حمايت معيوب و بى توجهى همسر به دليل بيمارى، مشكلات

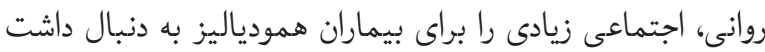

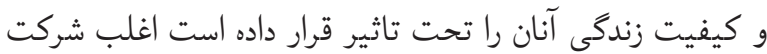


كيفيت زندگى بيماران تاثيركذار است وديكر براى مقابله با بيمارى و خودمراقبتى تلاش نمى كنند .

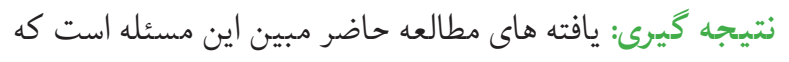
حمايت درك شده بيماران همودياليزى وشناسايى نقش هريك از

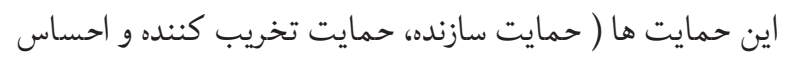

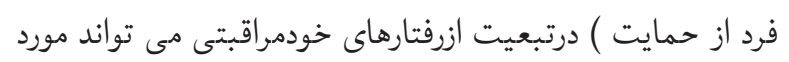

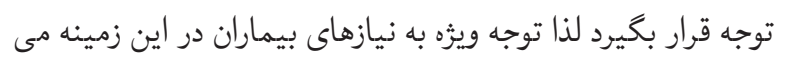
تواند منجر به بيامدهاى مفيدى گرددد.

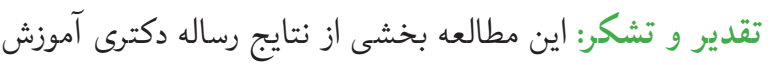

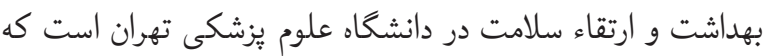

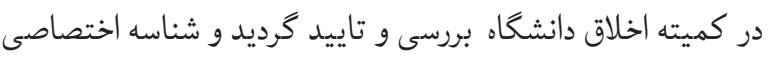
كميته اخلاق ( R.DTUMS.REC.1394.1665) مى باشد از كليه

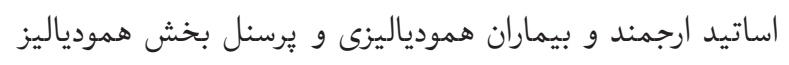
جهت همكارى در طول يُوهش تشكر مى كنم.

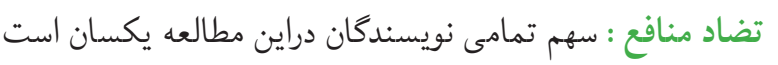
وهيجگُونه تضاد منافعى وجود ندارد .

\section{References}

1. Mazloomy Mahmoodabad SS, Tehrani H, Gholianaval $M$, Gholami $H$, Nematy $M$. The effect of social class on the amount of salt intake in patients with hypertension. Blood pressure. 2016;25(6):360-3. https://doi.org/10.1080/08037051.2016.1179508 PMid:27146368

2.Saei Azam MM, Ali Ebadi Abbas Effect of Continuous Care Model on dialysis adequacy in hemodialysis patients in military hospitals. J I m. 2017;1(2):105-12.

3. Borhani F, Bagherian S, Abaszadeh A, Ranjbar H, Tehrani $\mathrm{H}$, Soleimanizadeh L. Correlation between anxiety and pain due to intravenous catheters in children with thalassemia. Scientific Journal of Iranian Blood Transfusion Organization. 2012;9(2).

4.Aghakhani N. Application of Orem's theory of self-care nutritional program on quality of life in hemodialysis patients.in Hospitals training Uromeih. Jfh. 2016;1(2):4754

5.Moslem A, Naghavi M, Basiri Moghadam M, Basiri Moghadam. Assessing the adequacy of dialysis and its relationship with kind of filter in patient under hemodialysis referred to 22-Bahman hospital of Gonabad.

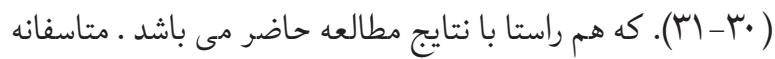
انتقال احساس ناتوانى از سوى اطرافيان به بيمار بسيار مضر و داراى ييامدهاى ناخوار مى باشد با بيماران دياليزى بايد همانند ساير افراد و نه يك بيمار ناتوان برخورد شود ـ انتقال احساس ناتوانى به دنبال بيمارى به فرد مبتلا سبب تضعيف روحيه و نا اميدى مى شود و بدتر اينكه اين تضعيف روحيه و انزوا به صورت درماندكى آموخته شده در مى آيد كه باعث كاهش انكيزه و عدم تبعيت از رفتارهاى خود مراقبتى مى شود روابط متقابل بين بيمار و اطرافيان و همراهى كردن بيمار در مراحل مختلف بيمارى بايد به گونه ایى باشد كه بيمار احساس سر بار بودن نكند آنجه بيمار بدان نياز دارد تنها همراهى كردن بيمار در رفت و آمد و غيره نيست بلكه او حس همدردى و محبت به خود را از سوى اطرافيان در يى اين بيمارى نياز دارد تا رعايت رفتارهاى خود مراقبتى را به خوبى و بدون دغدغه انجام دهد . نتايج مطالعه حاضر با مطالعه Rafatian همسوبود ( (r). بيماران احساس مى كنند كه زحمت و بار سنگينى با بيمارى به خانواده خود تحميل مى كنند درنتيجه احساس كناه مى كنند و رنج مى برند وبه تدريج ميل زندكى در آنها كاهش مى يابد كه بر

QH MS. 2008;14(2):3-20

6.Ersoy-Kart M. Vulnerability to stress, perceived social support and copping styles among chronic hemodialysis patients. Dial Transplant 2015; 34: 662-71

7. Sahranavard S, Ahadi H, Taghdisi MH, Kazemi T, Kraskian A. Relationship Between Perceived Social Support and Psychological and Social AdjustmentAmong Ischemic Heart Disease Patients. Iranian Journal of Health Education and Health Promotion. 2018;6(3):277-82. https://doi.org/10.30699/acadpub.ijhehp.6.3.277

8.Plantinga LC, Fink NE, Harrington-Levey $R$, Finkelstein FO, Hebah N, Powe NR, Jaar BG. Association of social support with outcomes in incident dialysis patients. Clin J A SN. 2014; 5(4):1480-88 https://doi.org/10.2215/CJN.01240210 PMid:20430940 PMCid:PMC2924404

9.RezaiyKargar F, Karbandi S. Social Support and diet compliance in type II diabetic patients. I J N 2004; 17(3): 12-16

10. Braun V, Clarke V. Using thematic analysis in psychology. Qual Res in psychol 2006;3(2):77-101 https://doi.org/10.1191/1478088706qp063oa 
11.owen sv,lev el .aprospective study of asdjustment to hemodiyalysis.ANNA.1998 ;25(5):495-503 https://doi.org/10.1016/S0191-8869(98)00075-0

12.Boosman H,Visser -Meily JM,Mijer, Elsinga A .Evaluation of change in fatigue, selfefficacy and health -relatrd quality of life, after a group educational intervention programme for persons with neuromuscular diseases or multiple sclerosis :a pilot study .Disabil Rehabil .2011;33(8):690-6 https://doi.org/10.3109/09638288.2010.510176 PMid:20795918

13.NasrinRezaee, NaimehSeyedfatemi, AlirezaSalar, fereshtehGhaljaei. Identifying Health Seeking Behaviors among Middle-aged Women: A Qualitative Study.JMU MS .2016; 26(140): 175-186

14.Sit JW, Wong TK, Clinton M, Li LS, Fong YM Stroke care in the home: the impact of social support on the general health of family caregivers. J ClinNurs 2004, 13(7): 816-24 https://doi.org/10.1111/j.1365-2702.2004.00943.x PMid:15361155

15.Corbin ,J.struss ,A .Basics of Qualitative Research : Techniques and procedures for developing grounded theory .3rd ed .california :sage publication .2008 https://doi.org/10.4135/9781452230153

16. Polaschek $N$. The experience of living on dialysis: $A$ literature review. Nephrol Nurs J. 2003;30(3):303-13

17. Zamanzadeh V, Heidarzadeh M, OshvandiKh, Lakdizaji S. Relationship between Quality of Life and Social Support in Hemodialysis Patients. J T U M S. 2007;29(1):49-54

18. Ell K. Social networks, social support and coping with serious illness: the family connection. Soc Sci Med.2017;42(2):173-83 https://doi.org/10.1016/0277-9536(95)00100-X

19. Kovac JA, Patel SS, Peterson RA, Kimmel PL. Patient satisfaction with care and behavioral compliance in end-stage renal disease patients treated with hemodialysis. Am J Kidney Dis. 2002;39(6):1236-44 https://doi.org/10.1053/ajkd.2002.33397 PMid:12046037

20.Ucelli MM, Mohr LM, Battaglia MA, Zagami P, Mohr DC. Peer support groups in multiple sclerosis: current effectiveness and future directions. Multiple Sclerosis. 2004;10(1):80-4 https://doi.org/10.1191/1352458504ms973oa PMid:14760957

21. Polaschek N. The experience of living on dialysis: $A$ literature review. NephrolNurs J. 2003;30(3):303-313

22. Demaille-Wlodyka S, Donze C, Givron P, Gallien P. ETP Sofmer Group. Self care programs and multiple sclerosis:physical therapeutic streatment literature review. Ann PhysRehabil Med. 2011; 54(2):109-28. https://doi.org/10.1016/j.rehab.2011.01.003 PMid:21388907

23. Boosman H, Visser-Meily JM, Meijer JW, Elsinga A,
Post MW. Evaluation of change in fatigue,selfefficacy and health-related quality of life, after a group educational intervention programme for persons with neuromuscular diseases or multiple sclerosis: a pilot study. DisabilRehabil. 2011; 33(8):690-6. https://doi.org/10.3109/09638288.2010.510176 PMid:20795918

24. -Farahani MN. [Psychological aspects of coping and adjustment of infertility and role of psychologist]. J ReprodInfertil 2001;2(1): 53-7

25. Rafii F, Soleimani M, Seyed-Fatemi N. Concept analysis of participation of patient with chronic disease: use of hybrid model. Ij n. 2010; 23(67):35-48

26. Gardner KG, Wheeler EC. Patients perceptions of support. West J OfNurs Res. 1987; 9(1):115-31 https://doi.org/10.1177/019394598700900110 PMid:3647701

27. de Ruiter JH, de Haes JC, Tempelaar R. Cancer patients and their network: The meaning of the social network and social interactions for quality of life. Supportive Care in Cancer.2015;1(3):152-5 h tt p s : / / o i .org / 10.1007 / B F 00366062 PMid:8149143

28. Vinicius CO, Kathryn MR, Manuela LF, Rafael ZP, Paula $\mathrm{RB}$, Ruben FNF et al. Communication that values patient autonomyisassociated withsatisfaction withcare:asystemic review. Journal of physiotherapy. 2012; 58(8):215-229. https://doi.org/10.1016/S1836-9553(12)70123-6

29. Williams GC, Freedman ZR, Deci ED. Supporting autonomy motivate patients with diabetes for glucose control. Diabetes Care.2016; 21(10):1644-1651 https://doi.org/10.2337/diacare.21.10.1644 PMid:9773724

30..Dadkhah B, Mozafari N. the trauma patients' sense of social limitation in adaptability with Ampotension: a qualitative study, the journal of nurses and doctors in battle. winter2014, : 5 (2):183-192

31. Hassankhani H, Taleghani F, Mills J, Birks M, Francis $K$, Ahmadi F. The challenges experienced by Iranian war veterans living with chemical warfare poisoning: a descriptive, exploratory study. Scandinavian journal of caring sciences. 2010;24(2):290-8 https://doi.org/10.1111/j.1471-6712.2009.00719.x PMid:20230514

32. Rafatian A. family members' companionship during the disease phase: a qualitative study. The j Tums; 5 (2) winter 2008 